TẠP CHÍ KHOA HỌC ĐẠI HỌC TÂN TRÀO

ISSN: $2354-1431$

http://tckh.daihoctantrao.edu.vn/

\title{
THE EFFECT OF CLASSROOM CLIMATE ON STUDENT ACADEMIC MOTIVATION MEDIATED BY ACADEMIC SELF - EFFICACY AT HANOI LAW UNIVERSITY
}

\author{
Pham Thi Anh Hang ${ }^{1, *}$ \\ ${ }^{1}$ Hanoi Law University, Vietnam \\ *Email address: anhhanghlu@gmail.com \\ https://doi.org/10.51453/2354-1431/2021/488
}

\section{Article info}

Recieved:

04/12/2020

Accepted:

$22 / 02 / 2021$

\section{Keywords:}

Classroom climate, academic motivation, academic selfefficacy, academic performance

\begin{abstract}
$\overline{\text { Learning strateries and efforts have popularly recognized academic motivation }}$ as the driving force of student academic performance. The present study examines the direct and indirect effect of classroom climate on student academic motivation at the tertiary level. A sample population of 119 freshmen from Hanoi Law University was approached to respond to a questionnaire. The result shows that classroom climate positively affects student academic motivation and that the relationship is significantly mediated by academic selfefficacy. Particularly, the findings indicate that a favourable classroom climate can effectively improve student academic motivation, the planned and fair classroom climates effectually build students' self-efficacy in their learning. This study highlights the indispensable and pivotal role that a planned, cohesive, and fair classroom climate plays in motivating students to learn. Moreover, it provides references for policymakers, school administrators, and lecturers in building a positive and healthy classroom climate.
\end{abstract}


TẠP CHÍ KHOA HỌC ĐẠI HỌC TÂN TRÀO

ISSN: $2354-1431$

http://tckh.daihoctantrao.edu.vn/

\title{
SỰ TÁC ĐộNG CỦA MÔI TRƯờnG HỌC LÊN ĐộNG CƠ HỌC TẬP ẢNH HƯỞNG BỞI NĂNG LỰC HỌC CỦA SINH VIÊN TRƯỜnG ĐẠI HỌC LUẠTT HÀ NỘI
}

\author{
Phạm Thị Ánh Hằng, \\ ${ }^{1}$ Truò̀ng Đại học Luật Hà Nội, Việt Nam \\ *Địa chỉ email: anhhanghlu@gmail.com \\ https://doi.org/10.51453/2354-1431/2021/488
}

Thông tin tác giả

Ngày nhận bài:

04/12/2020

Ngày duyệt đăng:

$22 / 02 / 2021$

Tù̀ khóa:

Môi trừ̀ng hoc, động $\mathrm{co}^{\circ}$ hoc tập, năng lục học, quá trình hoc

\section{Tóm tắt:}

Chiến lược học và nỗ lực học tập tốt được coi như là động lực học để thúc đẩy sinh viên có kết quả học tập tốt. Nghiên cứu này xem xét sự tác động trực tiếp và gián tiếp của môi trường học đối với động cơ học tập của sinh viên đại học. 119 sinh viên đại học của trường Đại học Luật Hà Nội được lựa chọn làm mẫu nghiên cứu trả lời phiếu điều tra. Kết quả chỉ ra rằng không khí lớp học có tác động tích cực đến động cơ học tập của sinh viên và mối liên hệ này có sự ảnh hưởng của năng lực học của sinh viên. Đặc biệt kết quả cũng chỉ ra rằng một môi trường học tốt có thể cải thiện đến động lực học và một không khí lớp học công bằng sẽ cải thiện tốt năng lực học của sinh viên. Nghiên cứu này làm sáng tỏ vai trò thiết yếu của môi trường học tác động đến việc học của sinh viên. Hơn nữa nghiên cứu này là nguồn tham khảo hữu ích cho nhà lập chính sách, quản trị trường học và giảng viên trong việc xây dựng môi trường học tích cực.

\section{Introduction}

Learning strategies and efforts have a great influence on students's perception and clearly posited the crucial role that academic motivation plays in facilitating student academic performance $[1 ; 2 ; 3]$. The effective learning process results from the triggering of academic motivation. Students who find interested, valueable, and enjoyable in the learning process, indicate more engagement, persistence in learning activities. As a result, strongly motivated students make more efforts to complete tasks, and display higher levels of academic achievement [4]. It is, however, quite challenging to encourage a low-level academic motivation among undergraduate students as they do not want to lose their face in the classroom, which can be easily spotted among non-major students who learn English as a foreign languge (EFL). Among the school factors, the preceding studies tend to investigate the well-known effects of teachers on students' academic motivation, limited information is offered to the effect of classroom climate on student academic motivation and how the effect happens in higher education setting in Vietnam. Motivation could be considered as the driving force in any situation that leads to action. In the field of language learning a distinction is sometimes made between an orientation, a class of reasons for learning a language, and motivation itself, which refers to a combination of the learner's attitudes, desires, and willingness to expend effort in order to learn the second language. Orientations include a motivation integrative orientation, characterized by a willingness to be like valued members of the language community, and an instrumental orientation towards more practical concerns such as getting a job or passing an 
examination. The construct of integrative motivation, therefore, includes the integrative orientation, positive attitudes towards both the target language community and the language classroom and a commitment to learn the language. Another widely cited distinction is between intrinsic motivation, enjoyment of language learning itself, and extrinsic motivation, driven by external factors such as parental pressure, societal expectations, academic requirements, or other sources of rewards and punishments. Other theories of motivation emphasize the balance between the value attached to some activity and one's expectation of success in doing it, goal setting, the learner's attributions of success and failure, the role of self-determination and learner autonomy, and the characteristics of effective motivational thinking. Motivation is generally considered to be one of the primary causes of success and failure in second language learning. The importance of motivation among students is often neglected and a few studies have conducted to highlight its role in educational contexts. This study investigated the relationship among 3 entities - classroom climate, academic motivation, and academic self-efficiency.

\section{Literature Review}

\subsection{Self-determination theory}

This study takes a self-determination theory (SDT) approach to understand student motivation in the classroom context. SDT unfolds a remarkable framework entailed of several motivation theories to understand the reciprocity of sociocultural conditions and individual personality. Besides the internationalization of motivation from external to internal, SDT also emphasizes the concept of basic psychological needs. SDT theorists believe that three psychological internal needs in human nature need to be met through their interaction with the environment: autonomy, or the desire to establish inner coherence and to feel self-directed; competence, or the needs to feel confident in one's interactions with the social environment through exercising and expressing one's abilities; relatedness, or the desire to feel integral and connected with others. Accordingly, the environment that satisfies or fulfills students' basic needs is predicted to support their self-motivation, engagement, and well-being. That is, the extent to which students' psychological needs are met by the perceived classroom climate is expected to be associated with their motivation to learn.
In order to differentiate short-term motivation from long-term motivation, SDT maps Hierarchal Model to category motivation into three levels: global, contextual, and situational. The global level is highly abstract since the motivational orientations of an individual were out of personal identity. The contextual level is less abstract as it describes the perceived relationship of an individual to other concrete materials or organizations like schools. The situational level, which is the focus of this study, is more specific compared to global and contextual levels, because it depicts an individual's motivational response to a specific activity. In the educational settings, student's general feelings towards school and learning affect his or her approaches to the learning environment and tasks. Conversely, classroom learning activities can affect the way student approaches learning in general [7].

\subsection{Academic motivation}

Conceptualized in the context of SDT, academic motivation is the driving force that empowers students to learn or participate in the learning proces. Academic motivation is usually divided into intrinsic motivation and extrinsic motivation. Intrinsic motivation has been conceptualized as the internal driving force of an individual to participate in a particular activity for his curiosity, interest, or fulfillment. It is linked with other components like exploration, learning goals, and intrinsic intellectuality. In contrast, extrinsic motivation is an inducement for a person to participate in a particular activity so as to gain rewards or to avoid punishment.

Academic motivation is recognized as one of the most effective driving force of student learning as well as the only factor that guarantees students' academic achievement. Among the numerous factors contributing to students' performance and academic achievement, academic motivation is considered as one of the ultimate elements. It helps to enhance students' engagement, learning autonomy, and academic performance in teaching and learning processes.

\subsection{Classroom climate}

Classroom climate is conceptualized as the intellectual, physical, emotional, and social environment in which students learn. It includes the physical environment of the classroom, the interaction between teacher and students, and teacher's behavioral and academic expectations of 
the students. Empirical evidence suggests that a self-governed and healthy environment in the classroom positively contributed to students learning outcomes, and academic motivation. A classroom with a teacher's coaching and inspiration will lead to coaching and encouragement among students, and further, bring about motivation enhancement and prolong student engagement. Students in a teacher-supported and teacherinvolved classroom indicates a higher level of motivation, gain more enjoyment in the learning process, and have more potential to achieve academic success; whereas, students in a classroom of teacher control and peer-competition are more likely to face challenges like learning-weariness, and anti-school feelings. In preceding work, we find that a classroom climate of involvement, autonomy, and meaningfulness advances student motivational goal orientation [6]. A classroom with good interpersonal relationship promotes student intrinsic motivation. Conversely, a negative classroom climate with poor peer relationships deters the growth of students' autonomous motivation in mathematics. Additionally, in an agreeable and pleasant classroom climate, students feel safer, have more confidence in learning, and are not afraid of making mistakes. A classroom climate of order significantly leads to the increase of reading motivation of efficacy, compliance, challenge, and aesthetics, and the whole process contributes to greater student academic achievement. Specifically, a teacher-centered classroom climate facilitates undergraduates' selfefficacy in mathematics learning.

\subsection{Academic self-efficacy}

Academic self-efficacy is conceptualized as one's confidence in his or her ability to complete learning tasks or achieve educational goals. It is found to be multi-faceted, and could impact how individuals feel, think, and carry out instructive assignments. Self-efficacy is developed on four bases of information, and they are vicarious experiences, enactive mastery as well as physical and emotional states. As such, academic selfefficacy could be pertinent for student educational performances as it comes along with corresponding behaviors and motivations that empower or debilitate compelling execution.

Scholars have posited that positive teaching and learning outcomes rely on affective and psychological factors like self-efficacy. Students, who believe that they have enough capacities to complete tasks, tend to take specific actions to achieve their learning goals, which will bring about academic outcomes and success. Additionally, Verešová, M., \& Foglová [9] argued that student academic self-efficacy was resolutely associated with their academic motivation and contributed to their learning performance as well as academic achievement. Other Empirical researches also confirmed that the positive effect of student selfefficacy on their academic motivation [8]. These findings are reinforced by recent experimental research demonstrating that the training of selfefficacy-building strategies significantly contribute to the improvement of student academic selfefficacy and motivation. In addition, the result also confirms the causal-effect relationship between academic self-efficacy and student motivation [10].

\subsection{Present study}

Recent research conducted by Huang and Bai [11] has found the positive influence of classroom climate on undergraduates' academic motivation and the mediating effect that self-efficacy exerts in their relationship. However, Huang and Bai [11] did not take account of other factors regarding classroom climate except for classmate relation and teacher support, nor did they test the reliability and validity of the research instrument, which makes the findings questionable. Thus, this study explicitly purposes to illustrate the relationship among classroom climate, student academic motivation, and self-efficacy among undergraduate students in Vietnam. On the strength of the above mentioned theoretical and empirical research approaches, three research questions are formulated for the present study as follows:

1. How are perceived classroom climate and academic self-efficacy related to student academic motivation?

2. Which dimension of perceived classroom climate significantly predicts student academic motivation and academic self-efficacy?

3. Does academic self-efficacy have a mediating effect on the relationship between classroom climate and student academic motivation?

\section{Method}

\subsection{Research Design}

A quantitative design and survey strategy were used to meet the research objectives. Data were drawn from 119 freshmen from a Hanoi Law 
University (HLU). In the sample students, there are 25 males (21\%) and 91 females (76.5\%). The average age of 2 the participants are $21(S D=1.4)$. The questionnaire was distributed to all undergraduate students $(N=2325)$ via email. It is a pity that only 119 students filled in the questionnaire. In PLS-SEM, the needed sample size could be calculated by means of power analyses according to the part of the model obtaining the largest number of predictors [12]. Hair, et al. [12] further suggested researchers use programs such as $G^{*}$ Power to do power analysis specific to model set-ups when utilizing PLS-SEM. G*power is a free online software used to do power analysis and sample size calculation. The analysis result of $G^{*}$ Power shows that the required sample size of this study is 92 (effect size $=.15, \alpha=.05, \beta=.80$, No. of predictor $=5$ ), indicating that 119 samples are adequate for data analysis and the sample size does not have an effect on the result.

\section{Instruments}

The current study used a questionnaire adopted from several scales. These scales consisted of a total of 43 items with a numerical rating scale ranging from 1 (not agree at all) to 9 (highest agreement). As a first step, the instrument was sent to three experts to validate the content. Then, a panel of bilingual experts was invited to validate the translation via a double back translation technique.

\section{Classroom Climate}

Classroom climate was assessed by Classroom Climate Questionnaire (CCQ). The CCQ is a 26item questionnaire to assess undergraduate students' perception of classroom climate in a college course. Classroom climate questionnaire includes five dimensions: a) cohesive, b) supportive, c) participative, d) planned, and e) fair. Cohesive dimension mainly reflects the extent to which students learn from each other, help each other, and support each other in the classroom. Supportive dimension focuses on the degree to which teachers are friendly, trustful, interested, and helpful to students in the classroom. Participative dimension reflects the degree of students' concentration, interest, and participation, and enjoyment in classroom discussion and learning. Planned dimension concerns the extent to which students complete classroom activities, goals, and tasks. Fair dimension regards the degree to which students are treated fairly by teachers. Reliabilities of the five dimensions are .904 (cohesive, $n=6$ item), .921 (supportive, $n=6 \quad$ item), .911 (participative, $n=4$ item), .876 (planned, $n=5$ item), and .929 (fair, $n=5$ item). The result of confirmative factor analysis reveals that the indicator loading of each item is higher than .70, and AVE value of each dimension is in the range of .67 -.80. In addition, the HTMT value of each dimension is smaller than .85 .

Academic self-efficacy

Academic self-efficacy was measured by a subscale titled Self-efficacy for Learning and Performance of Motivated Strategies for Learning Questionnaire (MSLQ). The sub-scale was utilized to measured the level of students' perceived ability and confidence in a course. MSLQ was designed on the basis of a general cognitive perspectives on learning motivation and strategies and a theoretical framework. This instrument has been widely used for many years and has been tested as reliable and valid in contemporary researches. The reliability test indicates a high reliability of this scale. The reliability of the self-efficacy is .936 ( $n=8$ item). The result of confirmative factor analysis reveals that the indicator loading of each item is higher than .70, AVE value is .71, HTMT value is smaller than .85 .

\section{Student Academic Motivation}

Student academic motivation was measured by a sub-scale (i.e. goal orientation) of MSLQ. The goal orientation regards students' goals to a subject or course as a whole, i.e., academic motivation. Intrinsic goal orientation assessed students' selfperceived degrees to participate in learning tasks out of reasons like interest, curiosity, challenge. Extrinsic goal orientation regards students' selfperceived degrees to participate in learning tasks out of reasons for example grades, rewards, competing with others, or evaluation by others. Therefore, this study adopts an intrinsic goal orientation to evaluate intrinsic motivation and extrinsic goal orientation to assess extrinsic motivation. Reliabilities of the two dimensions are 842 (intrinsic, $n=4$ item), and .866 (extrinsic, $n=4$ item). The result of confirmative factor analysis shows that the indicator loading of each item was higher than .70, and AVE value of each dimension is .68 and .72 respectively. Additionally, the HTMT value of each dimension is smaller than .85 .

\subsection{Results}

Table 1 summarizes the descriptive statistics of classroom climate (CC), self-efficacy (SE), 
academic motivation (AM), and the sub-constructs of classroom climate and academic motivation. The means of all constructs were higher than 6.34, indicating that students showed a generally high level of perceived academic self-efficacy, academic motivation, and classroom climate.

Table 1. Mean, SD, Skewness and Kurtosis of constructs

\begin{tabular}{|c|c|c|c|c|}
\hline Construct & Mean & SD & Skewness & Kurtosis \\
\hline Cohesive & 7.49 & .96 & -.54 & -.08 \\
\hline Supportive & 6.42 & 1.29 & -.54 & .47 \\
\hline Participative & 6.64 & 1.29 & -.61 & .74 \\
\hline Planned & 7.31 & .96 & -.37 & -.18 \\
\hline Fair & 7.23 & 1.18 & -.62 & .13 \\
\hline Intrinsic & 7.34 & .99 & -.64 & .18 \\
\hline Extrinsic & 7.52 & 1.08 & -.66 & .18 \\
\hline SE & 7.04 & 1.09 & -.39 & -.21 \\
\hline $\mathrm{AM}$ & 7.43 & .94 & -.67 & .17 \\
\hline $\mathrm{CC}$ & 7.02 & .96 & -.34 & -.48 \\
\hline
\end{tabular}

With regard to the first research question, Pearson correlations were employed to analyze the relationship between perceived classroom climate, academic self-efficacy, and academic motivation using SPSS 24. Inter-correlations among the ten constructs are shown in Table 2 . The result revealed strong correlation between classroom climate and academic self-efficacy $(r=.75, p<.001)$, classroom climate and academic motivation $(r=.66, p<.001)$, and students' self-efficacy and their academic motivation $(r=.75, p<.001)$. Unexpectedly, all the constructs were also strongly associated.

Table 2. Inter-correlations among constructs

\begin{tabular}{|c|c|c|c|c|c|c|c|c|c|}
\hline Construct & 1 & 2 & 3 & 4 & 5 & 6 & 7 & 8 & 9 \\
\hline 1. CC & 1 & & & & & & & & \\
\hline 2. AM & $* .66^{* *}$ & 1 & & & & & & & \\
\hline 3. SE & $* .75^{* *}$ & ${ }_{* *} .75^{*}$ & 1 & & & & & & \\
\hline 4. Cohesive & * $.79^{* *}$ & ${ }_{* *} .63^{*}$ & ${ }_{* *} .60^{*}$ & 1 & & & & & \\
\hline 5. Supportive & ${ }_{*} .86^{* *}$ & ${ }_{* *} .41^{*}$ & ${ }_{* *} .53^{*}$ & ${ }_{* *}^{.57^{*}}$ & 1 & & & & \\
\hline 6. Participative & ${ }_{*}^{*} .89^{* *}$ & ${ }_{* *} .48^{*}$ & ${ }_{* *} .61^{*}$ & ${ }_{* *} .62^{*}$ & ${ }_{* * *} .81^{*}$ & 1 & & & \\
\hline 7. Planned & $.83^{* *}$ & ${ }_{* *} .72^{*}$ & ${ }_{* *} .75^{*}$ & $.65^{*}$ & ${ }_{* *} .57^{*}$ & $.63^{*}$ & 1 & & \\
\hline 8. Fair & ${ }_{*} .83^{* *}$ & ${ }_{* *} .60^{*}$ & ${ }_{* *} .69^{*}$ & $.59^{*}$ & ${ }_{* *} .61^{*}$ & ${ }_{* *} .60^{*}$ & ${ }_{* *} .73^{*}$ & 1 & \\
\hline 9. Intrinsic & $.64^{* *}$ & ${ }_{* * *} .90^{*}$ & ${ }_{* *} .74^{*}$ & ${ }_{* *} .61^{*}$ & ${ }_{* *} .40^{*}$ & ${ }_{* *} .47^{*}$ & ${ }_{* *} .70^{*}$ & ${ }_{* *} .59^{*}$ & 1 \\
\hline 10. Extrinsic & ${ }_{*} .55^{* *}$ & ${ }_{* *} .92^{*}$ & ${ }_{* *} .62^{*}$ & ${ }_{* *} .53^{*}$ & ${ }_{* *} .35^{*}$ & ${ }_{* *} .39^{*}$ & ${ }_{* *} .62^{*}$ & ${ }_{* *} .49^{*}$ & ${ }_{* *} .65^{*}$ \\
\hline
\end{tabular}

Note. $* * *$ Correlation is significant at the .001 level (2-tailed)

In order to examine which dimension of perceived classroom climate significantly predicts student academic motivation and academic selfefficacy, stepwise multiple regression technique was employed to explore the causal-effect among the constructs. Table 3 illustrates the output of multiple regression analysis of the dimension of classroom climate on academic motivation and self-efficacy. 
Table 3. Multiple regression of classroom climate on academic motivation and self-efficacy

\begin{tabular}{|c|c|c|c|c|c|c|}
\hline $\begin{array}{l}\text { Dimension of Classroom } \\
\text { Climate }\end{array}$ & $b$ & $\beta$ & $t$ & Sig. & $\mathrm{R}^{2}$ & $\%$ \\
\hline Planned-> AM & .532 & .546 & 6.526 & .000 & .518 & 51.8 \\
\hline Cohesive-> AM & .265 & .271 & 3.244 & .002 & .557 & 3.9 \\
\hline Planned-> SE & .602 & .531 & 6.044 & .000 & .567 & 56.7 \\
\hline Fair-> SE & .281 & .304 & 3.462 & .001 & .603 & 3.8 \\
\hline \multicolumn{7}{|c|}{ 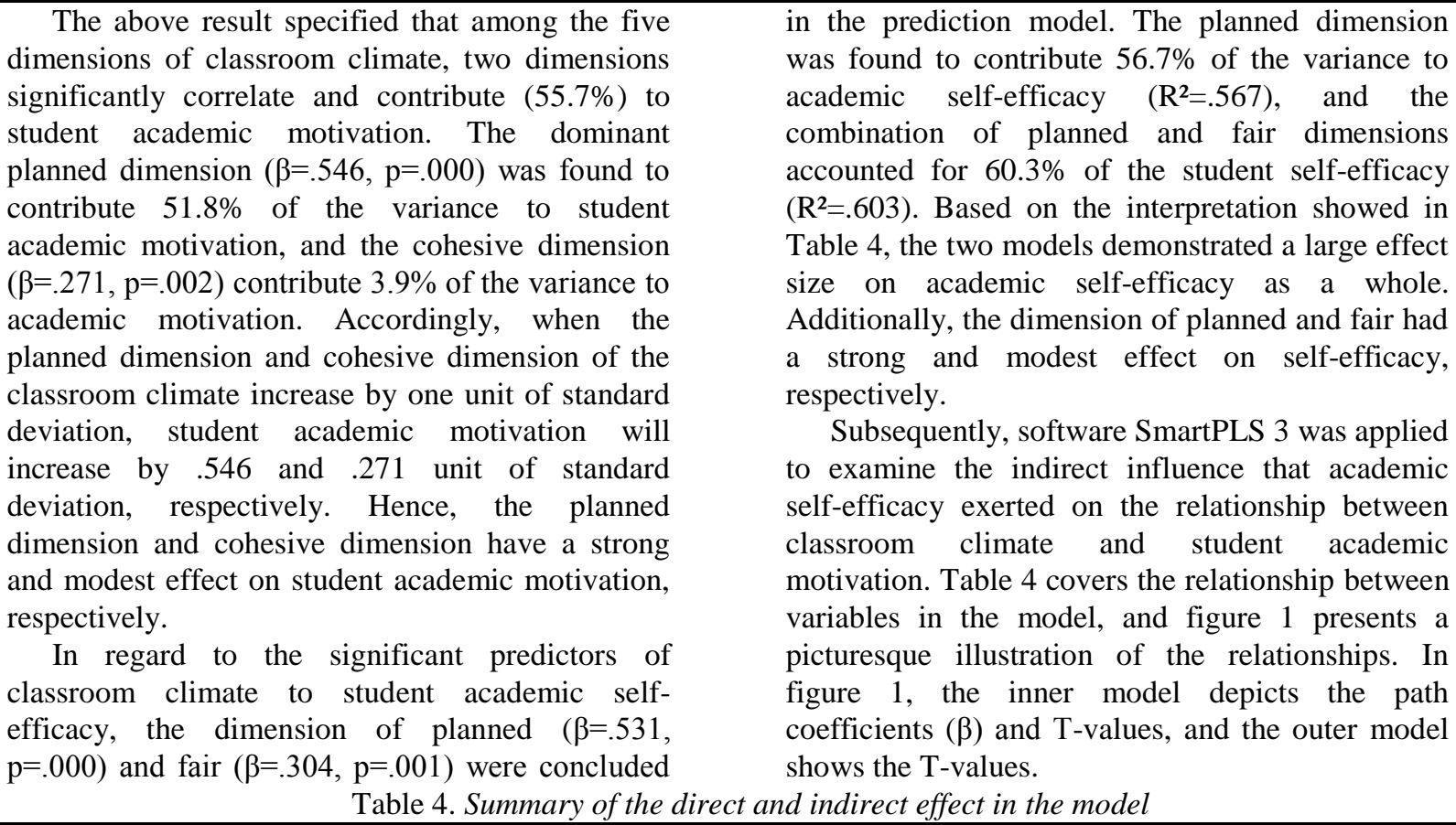 } \\
\hline Path & & \multicolumn{2}{|c|}{$\mathrm{t}$} & \multicolumn{2}{|c|}{ Sig. } \\
\hline $\mathrm{CC} \rightarrow \mathrm{AM}$ & \multicolumn{2}{|c|}{.242} & \multicolumn{2}{|c|}{2.454} & \multicolumn{2}{|c|}{.014} \\
\hline $\mathrm{CC} \rightarrow \mathrm{SE}$ & \multicolumn{2}{|c|}{.762} & \multicolumn{2}{|c|}{16.409} & \multicolumn{2}{|c|}{.000} \\
\hline $\mathrm{SE}->\mathrm{AM}$ & \multicolumn{2}{|c|}{.576} & \multicolumn{2}{|c|}{6.356} & \multicolumn{2}{|c|}{.000} \\
\hline \multicolumn{2}{|l|}{$\mathrm{CC} \rightarrow \mathrm{SE} \rightarrow \mathrm{AM}$} & & \multicolumn{2}{|c|}{5.688} & \multicolumn{2}{|c|}{.000} \\
\hline
\end{tabular}

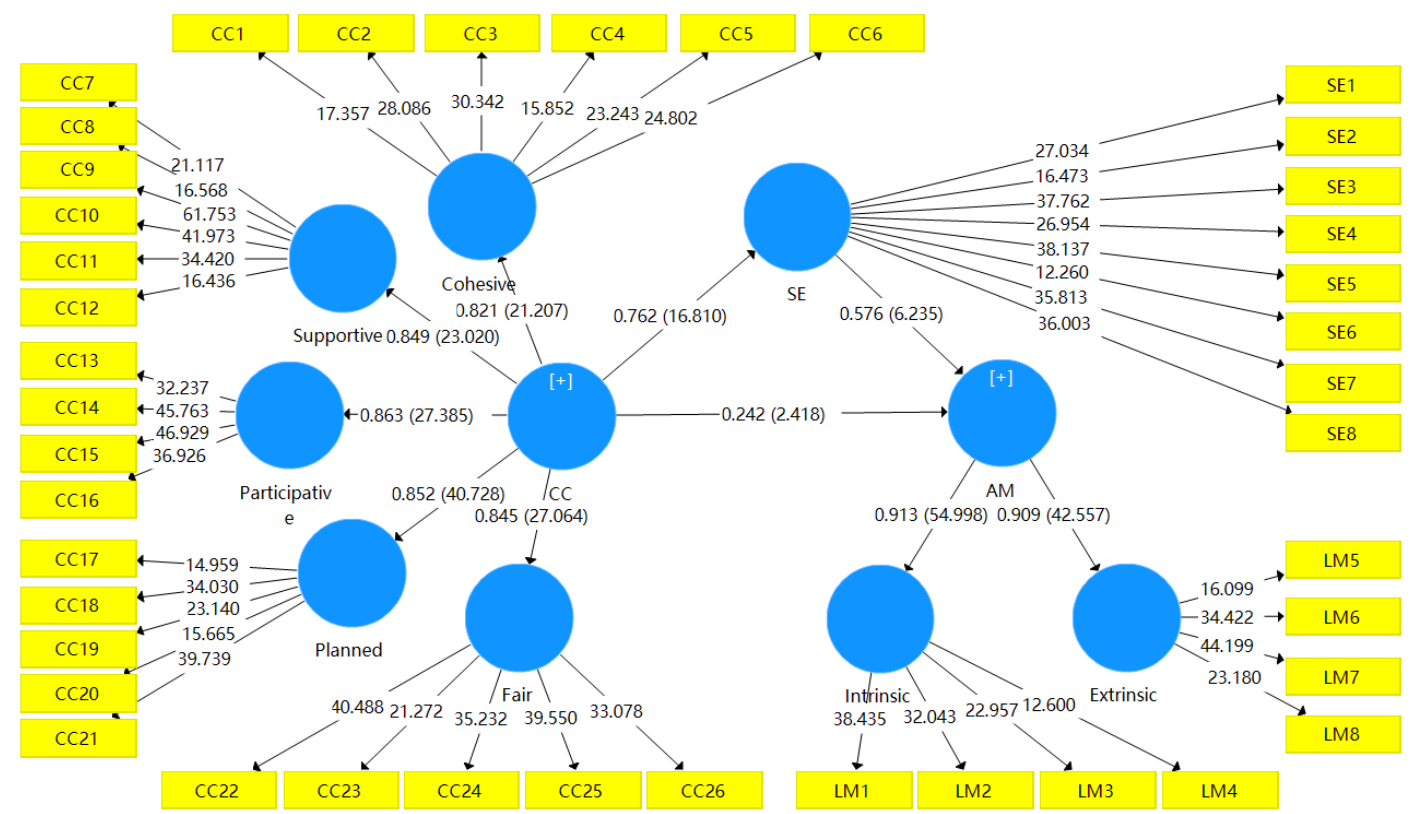

Figure 1. The Structural Model Assessment 
According to the output shown in figure 1 and table 4 , the direct effect of classroom climate on student academic motivation is estimated at $\beta=.242$, the indirect effect which is the multiplication of both indirect paths $(.762 \times .576)$ equals to .439 , leaving the standardized total effect (indirect + direct) at .681 . The direct path of classroom climate and academic motivation is supported; meanwhile, the two indirect paths (classroom climate academic self-efficacy - academic motivation) are also confirmed. The result reveals that academic self-efficacy partially mediates the relationship between classroom climate and student academic motivation since both direct and indirect effects are established.

\subsection{Discussion}

Results obtained from data analysis have a number of implications; however, they should be interpreted with SDT and previous related findings.

First, the classroom climate significantly and positively affects student academic motivation. Findings of this study affirm the research result of Huang and Bai [11] and [6] which indicated that a healthy and positive classroom climate was pivotal for the improvement of student academic motivation. Specifically, a cohesive classroom climate, in which students learn and support each other, significantly improves academic motivation. This is echoed by the findings noting that when secondary students felt a higher level of friendship in a classroom, they were more motivated to learn. More importantly, a planned classroom in which students complete classroom tasks in high quality, greatly contributes to the improvement of student academic motivation $\left(\mathrm{R}^{2}=51.8 \%\right)$. Nevertheless, this study also found that a supportive classroom climate was closely correlated with $(p<.001)$ but insignificantly influences student academic motivation. This is aligned with the previous findings that teacher support was indispensable for the enhancement of student academic motivation, however inconsistent with the findings of Huang and Bai [11] that teacher support significantly and positively influenced student academic motivation. A probable reason for this inconsistency could have been the participant characteristics. As adult learners, undergraduates are less affected by teachers compared with primary and secondary students. According to the latest research, medical students indicated a higher level of autonomy in learning. They have heavy learning tasks and devote a long time in learning so as to meet their higher academic requirements, making them live in a comparatively strong and competitive learning atmosphere. This atmosphere consequences further facilitates the development of their autonomy learning.

Second, the influence of classroom climate on student academic motivation is mediated by academic self-efficacy. The result is consistent with SDT and the findings reported in the research conducted at the tertiary context [11]. Students who believe that their psychological needs are met in the social environment or who study in a positive and healthy classroom climate, indicate a higher level of confidence in their ability and academic motivation. Third, a planned and fair classroom contributed to the improvement of self-efficacy. This is echoed by the research findings, which shows that a well-planned classroom climate helps to increase student reading motivation. When the students complete classroom learning tasks and were treated equally, it helps them to build their self-confidence to achieve their learning goals and then improves their motivation to pursue personal development. Fourth, the descriptive result recommends that the respondents of this study are highly motivated to learn. This is contradictory to the findings which indicate the insufficiency of academic motivation among college students. A conceivable explanation for this might be the better academic background of medical students compared with other disciplined students. In Vietnam, high school students need to get a higher score in the national college entrance examination so as to get the enrollment chance to be medical students. Finally, the planned dimension of classroom climate has a very robust impact on student motivation $(\beta=.546)$ and self-efficacy $(\beta=.531)$, indicating that among the three psychological needs, competence is the most important for undergraduate medical students in Vietnam. Overall, this finding is coordinated with the argument of SDT.

\section{Conclusion}

After analyzing the data collected from 119 students from HLU, the result concluded the significant influence that classroom climate exerted on student academic motivation and the mediating effect that academic self-efficacy occurs in the relationship. This study also indicated that among the five dimensions of classroom climate, a planned and fair classroom climate significantly improved student self-efficacy, and a cohesive and planned classroom climate help to motivate students to learn. This stresses the essential place of healthy and well-organized classroom climates to student 
learning. For policymakers and stakeholders, more related educational policies regarding classroom climate should be made and they can also set classroom climate evaluation as a criterion to assess education practitioners. For school administrators, they need to safeguard teachers' actions within the classroom are consistent with research-based factors advised by this study and previous literature to promote student academic motivation and performance. Also, school administrators can launch programs that can effectively facilitate the classroom climate to improve student academic motivation. For lectures, they can obtain the message that the conservation of a positive classroom climate is highly crucial and beneficial for students' academic performance. They can also build a classroom environment with a good classmate relationship, treat the students in an equivalent way, and offer them more prospects to complete learning tasks. More meaning should be embedded in the design of learning tasks to meet students' needs of competence, to build their confidence and motivation.

\section{REFERENCE}

[1] Cleary, T. J., Kitsantas, A. (2017). Motivation and self-regulated learning influences on middle school mathematics achievement. School Psychology Review, 46(1), 88-107. doi:10.17105/spr46-1.88-107

[2] Froiland, J. M., Worrell, F. C. (2016). Intrinsic motivation, learning goals, engagement, and achievement in a diverse high school. Psychology in the Schools, 53(3), 321-336. doi:10.1002/pits.21901

[3] Ladd, H. F., Sorensen, L. C. (2017). Returns to teacher experience: Student achievement and motivation in middle school. Education Finance and Policy, 12(2), 241-279. doi:10.1162/edfp_a_00194

[4] Supervia, P. U., Bordas, C. S. (2018). School Motivation, Emotional Intelligence and Academic Performance in Students of Secondary Education. Actualidades En Psicologia, 32(125), 95-112.
[5] Gao, X. L., Gao, L., (2015) The characteristics and grade differences in learning motivation, learning strategies, learning investment among undergraduate students. China Journal of Health Psychology, 23 (2), 274-277.

[6] Lerdpornkulrat, T., Koul, R., Poondej, C. (2018). Relationship between perceptions of classroom climate and institutional goal structures and student motivation, engagement and intention to persist in college. Journal of Further and Higher Education, 42(1), 102-115. doi:10.1080/0309877x.2016.1206855

[7] Stolk, J.D., Jacobs, J., Girard, C., Pudvan, L. (2018). Learners' Needs Satisfaction, Classroom Climate, and Situational Motivations: Evaluating Self-Determination Theory in an Engineering Context. 2018 IEEE Frontiers in Education Conference (FIE), 1-5. doi:10.1109/fie.2018.8658880

[8] Taheri-Kharameh, Z., Sharififard, F., Asayesh, H., Sepahvandi, M., Hoseini, M. H. (2018). Relationship between Academic Selfefficacy and Motivation among Medical Science Students. Journal of Clinical and Diagnostic Research, 12(7), 7-10. doi: 10.7860/JCDR/2018/29482.11770

[9] Verešová, M., Foglová, L. (2016). Academic self-Efficacy, heteronomous and autonomous evaluation of academic achievement of adolescents. Paper presented at the 7th International Conference on Education and Educational Psychology (ICEEPSY 2016). URL: http://dx.doi.org/10.15405/epsbs.2016.11.91

[10] Cave, P. N., Evans, N. W., Dewey, D. P., Hartshorn, K. J. (2018). Motivational partnerships: increasing ESL student self-efficacy. Elt Journal, 72(1), 83-96. doi:10.1093/elt/ccx027

[11] Huang, C., Bai, Q.-h. (2017). The Relationship Between Classroom Climate, SelfEfficacy, and Learning Motivation. DEStech Transactions on Social Science, Education and Human Science, 308-312. doi:10.12783/dtssehs/ermm2017/14731

[12] Hair Jr, J. F., Hult, G. T. M., Ringle, C., Sarstedt, M. (2017). A primer on partial least squares structural equation modeling (PLS-SEM) (Second ed.). Los Angeles: Sage publications. 